\title{
MENINGKATKAN HASIL BELAJAR SISWA MENGGUNAKAN MODEL PEMBELAJARAN KOOPERATIF TIPE STUDENT TEAM ACHIEVEMENT DIVISION (STAD)
}

\author{
Yunie Nurhazannah \\ SMP Negeri 21 Pontianak \\ E-mail: yunienurhazannah@gmail.com
}

\begin{abstract}
This study aims to determine the improvement of student learning outcomes in the system of linear equations of two variables using Student Team Achievement Division (STAD) type cooperative learning model in class VIII E SMPN 21 Pontianak academic year 2016/2017. Data collection was obtained by direct observation and test. Subjects are students of class VIII SMPN 21 Pontianak with 38 students of students consisting of 16 male students and 22 female students. This classroom action research consists of two cycles. Each cycle stage consists of planning, implementation, observation and reflection. The results of data analysis that replicate the first half of the academic year 2015/2016 shows that students who learn completeness of students has just reached 10.58\%. His performance is low. The instruments used in this classroom action research are: (1) Student Activity Observation Sheet; (2) Observation Sheet of teacher teachers in learning activities; (3) Written test (Test Cycle I and Cycle II). Results of learning data from the first cycle to cycle II obtained more than $75 \%$ of students who graduated. This study revealed that the use of cooperative learning model STAD can improve student learning outcomes on linear equations system in two variables E class VIII SMP Negeri 21 Pontianak.
\end{abstract}

Keywords: learning outcomes, Student Team Achievement Division (STAD), Systems of Linear Equations in Two Variables (SPLDV)

\begin{abstract}
Matematika sebagai ilmu dasar perlu mendapatkan perhatian yang cukup besar karena aktivitas keseharian manusia tidak terlepas dari kegiatan menghitung. Matematika merupakan cabang Ilmu Pengetahuan yang mempunyai peranan sangat penting dalam perkembangan Ilmu Pengetahuan dan Teknologi.
\end{abstract}

Matematika juga dapat menjadikan siswa menjadi manusia yang dapat berpikir secara logis, kritis, rasional dan percaya diri. Tetapi matematika sering dikatakan sebagai pelajaran yang sulit dipahami dan sangat menakutkan, baik teori maupun konsep-konsep sehingga menyebabkan prestasi belajar 
matematika belum menunjukkan hasil yang memuaskan.

Guru sering kali menghadapi masalah tentang rendahnya aktivitas dan hasil belajar siswa. Hal ini dapat dilihat dari hasil ulangan harian siswa, nilai tugas, dan nilai Ulangan Tengah Semester yang belum sesuai dengan harapan guru dan siswa dengan Kriteria Ketuntasan Minimal (KKM) yang sudah ditetapkan sekolah yaitu 74 .

Berdasarkan analisis hasil belajar sebelum penelitian, dari 38 siswa, hanya 4 siswa $(10,53 \%)$ yang mencapai KKM (KKM yang ditetapkan adalah 74) sedangkan yang tidak mencapai KKM 34 siswa $(89,47 \%)$ tergolong sangat rendah dengan rata-rata 40,84 jauh dari nilai KKM yang diharapkan. Sedangkan nilai tertinggi yang diperoleh adalah 84 dan nilai yang terendah adalah 24 , ini menunjukkan jangkauan yang sangat jauh

Pengalaman dan pengamatan penulis sebagai guru matematika di SMP Negeri 21 Pontianak yang telah lama mengajar khususnya pada kompetensi dasar menyelesaikan persamaan linear dua variabel dengan materi pokok Sistem Persamaan Linear Dua Variabel di kelas VIII, dalam proses pembelajaran seringkali ditemui masalah-masalah sebagai berikut: Siswa mengalami kesulitan dalam menyelesaikan soal persamaan linear dua variabel apalagi kalau sudah dikaitkan dengan soal cerita, soal semacam ini memuat kalimat sehari-hari yang perlu diolah terlebih dahulu kedalam model matematika. Pada saat proses belajar mengajar berlangsung sebagian besar siswa pasif. Selain itu sebagian besar siswa kurang memahami konsep dan sulit mengaitkan materi pelajaran dengan materi yang terkait sehingga nilai yang dicapai tidak memuaskan.

Peneliti menyadari banyak faktor yang menjadi penyebab rendahnya aktivitas dan hasil belajar siswa, salah satu penyebabnya penyampaian materi pembelajaran masih cenderung bersifat simbolik, kecenderungan ini menyebabkan pemahaman konsep matematika menjadi kurang bermakna. Faktor lain adalah cara guru mengajar yang masih berpusat pada guru. Dari pihak siswa, siswa tidak mau bertanya, tidak mau mengemukakan pendapat dan ragu serta kurang percaya diri terhadap penyelesaian soal yang dikerjakan. Sesekali dalam pembelajaran siswa berdiskusi, tetapi diskusi tidak berjalan sebagaimana mestinya. Hanya siswa yang pandai yang aktif dalam mengerjakan dan menyelesaikan lembar kerja siswa, sementara yang lain hanya mencatat hasil akhir, bahkan ada siswa yang tidak melakukan apapun dalam kegiatan diskusi.

Dari paparan diatas, peneliti menganggap perlu untuk menerapkan model pembelajaran dimana guru dapat memperbaiki cara penyajian dalam proses pembelajaran untuk dapat meningkatkan keaktifan siswa dalam proses pembelajaran, dimana siswa berdiskusi dan bekerja sama bersama-sama temannya untuk menguasai materi pelajaran, siswa yang pandai membantu siswa yang kurang pandai, sehingga diharapkan hasil belajar siswa dapat meningkat. Untuk meningkatkan aktivitas dan hasil belajar siswa dalam proses pembelajaran, peneliti menggunakan model pembelajaran Kooperatif tipe Student Team Achievement Division 
(STAD) sebagai sarana penunjang proses belajar mengajar.

Penelitian Idayani (2010) menunjukkan bahwa aktivitas siswa dalam diskusi kelompok meningkat ini terlihat dari siswa yang semula kurang aktif pada siklus I namun lebih aktif pada siklus II. Siswa-siswa yang pandai mulai bisa berbagi pengetahuan dengan siswa yang kurang pandai sehingga siswa secara bersama-sama mencapai ketuntasan dalam belajar. Antusias siswa dalam pembelajaran lebih baik dari pembelajaran yang dilakukan guru sebelumnya. Rochmatin \& Gunansyah (2014) menegaskan bahwa model pembelajaran kooperatif tipe STAD dapat meningkatkan aktivitas dan hasil belajar siswa. Aspek pengungkapan stimulus, presentasi hasil kerja kelompok, mengungkapkan pendapat merupakan kegiatan yang sangat memacu keaktifan siswa dalam pembelajaran. Peningkatan tersebut menjadikan peran guru sebagai sutradara dalam pembelajaran yang merupakan ranah penting dalam keberhasilan suatu pembelajaran. Langkah-langkah pembelajaran kooperatif tipe STAD didasrakan pada langkah-langkah kooperatif yang terdiri atas enam fase. Fase-fase tersebut disajikan dalam Tabel 1.

Tabel 1. Fase-fase pembelajaran kooperatif tipe STAD

\begin{tabular}{|c|c|}
\hline Fase & Kegiatan Guru \\
\hline $\begin{array}{l}\text { Fase } 1 \\
\text { Menyampaikan tujuan dan memotivasi } \\
\text { siswa }\end{array}$ & $\begin{array}{l}\text { Menyampaikan semua tujuan pelajaran yang } \\
\text { ingin dicapai siswa pada pelajaran tersebut } \\
\text { dan memotivasi siswa belajar }\end{array}$ \\
\hline $\begin{array}{l}\text { Fase } 2 \\
\text { Menyajikan/ menyampaikan informasi }\end{array}$ & $\begin{array}{l}\text { Menyajikan informasi kepada siswa dengan } \\
\text { mendemontrasikan atau lewat bahan bacaan }\end{array}$ \\
\hline $\begin{array}{l}\text { Fase } 3 \\
\begin{array}{l}\text { Mengorganisaikan } \quad \text { siswa } \\
\text { kelompok-kelompok belajar }\end{array}\end{array}$ & $\begin{array}{l}\text { Menjelaskan kepada siswa bagaimana caranya } \\
\text { membentuk kelompok belajar dan membantu } \\
\text { setiap kelompok agar melakukan transisi } \\
\text { secara efisien }\end{array}$ \\
\hline $\begin{array}{l}\text { Fase } 4 \\
\text { Membimbing kelompok belajar dan } \\
\text { belajar }\end{array}$ & $\begin{array}{l}\text { Membimbing kelompok-kelompok belajar } \\
\text { pada saat mereka mengerjakan tugas mereka }\end{array}$ \\
\hline $\begin{array}{l}\text { Fase } 5 \\
\text { Evaluasi }\end{array}$ & $\begin{array}{l}\text { Mengevaluasi hasil belajar tentang materi } \\
\text { yang telah diajarkan atau masing-masing } \\
\text { kelompok mempresentasikan hasil kerjanya }\end{array}$ \\
\hline $\begin{array}{l}\text { Fase } 6 \\
\text { Memberikan penghargaan }\end{array}$ & $\begin{array}{l}\text { Mencari cara-cara untuk menghargai baik } \\
\text { upaya maupun hasil belajar individu dan } \\
\text { kelompok }\end{array}$ \\
\hline
\end{tabular}

Sumber : Ibrahim, dkk (dalam Trianto, 2010:71) 
Menurut Slavin (dalam Idayani, 2010:19) ada lima komponen utama dalam pembelajaran kooperatif tipe STAD, yaitu :

a. Presentasi atau Penyajian Kelas; merupakan penyajian materi yang dilakukan guru secara klasikal dengan menggunakan presentasi verbal atau teks. Penyajian difokuskan pada konsep-konsep materi yang akan dibahas. Setelah penyajian materi, siswa bekerja pada kelompok untuk menuntaskan materi pelajaran melalui tutorial, kuis, atau diskusi.

b. Menetapkan siswa dalam kelompok; kelompok merupakan komponen yang paling penting dalam STAD. Kelompok yang dibentuk sebaiknya terdiri dari satu siswa kelompok atas, dua siswa kelompok tengah dan satu siswa dari kelompok bawah. Kelompok terdiri dari 4-5 siswa yang mewakili dari seluruh bagian dari kelas baik dalam hal akademik maupun jenis kelamin. Fungsi dibentuknya kelompok adalah untuk saling menyakinkan bahwa setiap anggota kelompok dapat bekerja sama dalam belajar. Lebih khusus lagi untuk mempersiapkan semua anggota kelompok dalam menghadapi tes individu dan mencetak poin yang tinggi untuk kelompoknya. Ketika mendiskusikan masalah, kerja pada kelompok yang paling penting adalah memperbaiki setiap kekeliruan apabila teman sesama dalam kelompok membuat kesalahan.

c. Tes dan Kuis; Tes atau kuis diberikan setelah pemberian materi ajar oleh guru, presentasi kelompok dan latihan dalam kelompok. Para siswa mengerjakan kuis individual. Siswa tidak diperbolehkan saling membantu selama kuis berlangsung. Hal ini menjamin agar secara individual bertanggung jawab untuk memahami materi yang diajarkan guru. Siswa harus menyadari bahwa usaha dan keberhasilan mereka nantinya akan memberikan sumbangan berharga bagi kesuksesan kelompok

d. Skor Kemajuan Individu; Setiap siswa diberikan sebuah skor dasar yang dihitung dari rata-rata nilai siswa pada kuis sebelumnya. Skor kemajuan individu bertujuan untuk memberikan tujuan kinerja yang dapat dicapai oleh siswa apabila mereka bekerja lebih giat dan mampu menunjukkan perkembangan yang lebih baik dari kuis sebelumnya. Poin yang disumbangkan siswa pada kelompoknya didasarkan pada beberapa skor kuis mereka melampui skor sadar mereka. Setiap siswa dapat menyumbangkan poin maksimum kepada kelompoknya dalam sistem penskoran ini. Untuk menghitung perkembangan skor individu dapat dilihat pada Tabel 2. 
Tabel 2. Perhitungan perkembangan skor individu

\begin{tabular}{clc}
\hline No & \multicolumn{1}{c}{ Nilai Tes } & Poin \\
\hline 1 & Pebkembangan dari 10 poin dibawah skor dasar & 5 poin \\
\hline 2 & 10 sampai 1 poin dibawah skor dasar & 10 poin \\
\hline 3 & Skor 0 samapi 10 poin diatas skor dasar & 20 poin \\
\hline 4 & Lebih dari 10 poin diatas skor dasar & 30 poin \\
\hline 5 & Nilai sempurna (tanpa memperhatikan skor dasar) & 30 poin \\
\hline
\end{tabular}

Sumber : Trianto,2010:72

e. Rekognisi kelompok / Penghargaan Kelompok; Penghargaan kelompok dilakukan dengan memberikan penghargaan atas usaha yang telah dilakukan kelompok selama belajar. Kelompok dapat diberi sertifikat atau bentuk penghargaan lainnya jika dapat mencapai kriteria yang telah ditetapkan seperti yang terlihat dalam Tabel 3.

Tabel 3. Tingkat penghargaan kelompok

\begin{tabular}{cc}
\hline Rata-rata Tim & Predikat \\
\hline $0 \leq x \leq 5$ & - \\
\hline $5 \leq x \leq 15$ & Tim Baik \\
\hline $15 \leq x \leq 25$ & Tim Hebat \\
\hline $25 \leq x \leq 30$ & Tim Super
\end{tabular}

Sumber : Trianto,2010:72

Dimyati dan Mujiono (2006) mengemukakan bahwa hasil belajar adalah hasil yang dicapai dalam bentuk angka-angka atau skor setelah diberikan tes hasil belajar pada akhir pembelajaran. Nilai yang diperoleh menjadi acuan untuk melihat penguasaan siswa dalam menerima materi pelajaran.

Dari uraian diatas dapat disimpulkan bahwa hasil belajar merupakan hasil perubahan tingkah laku siswa yang menyangkut domain kognitif (pengetahuan), afektif (sikap) dan psikomotorik (keterampilan) yang timbul akibat dari kegiatan belajar yang dilakukan siswa. Hasil belajar dalam penelitian ini adalah nilai yang diperoleh siswa dari test yang diberikan sesudah pembelajaran pada materi SPLDV dengan menggunakan model pembelajaran kooperatif tipe STAD. Untuk melihat hasil belajar perlu dilakukan suatu penilaian terhadap siswa yang bertujuan untuk mengetahui apakah siswa telah menguasai suatu materi atau belum.

Untuk meningkatkan aktivitas dan hasil belajar siswa dalam proses pembelajaran, peneliti menggunakan pembelajaran kooperatif tipe STAD, karena dalam pelaksanaannya model pembelajaran koopreatif tipe STAD lebih memudahkan siswa dalam memahami materi yang disajikan guru, siswa menjadi lebih aktif dalam proses pembelajaran karena secara berkelompok siswa dilatih untuk bekerjasama, menghargai pendapat teman dan mengajarkan makna keberagaman kepada siswa. Untuk itu peneliti tertarik untuk melakukan penelitian tindakan kelas dengan judul "Meningkatkan Hasil Belajar Siswa Menggunakan Model Pembelajaran Kooperatif Tipe Student Team Achievement Division (STAD)". 


\section{METODE}

Rancangan Penelitian
Tindakan Kelas (PTK) dimana
peneliti mengalami secara langsung
objek di lapangan yang meliputi dua
siklus pembelajaran, satu tahapan
siklus meliputi perencanaan,
pelaksanaan, observasi (pengamatan)
dan refleksi. Subjek dalam penelitian
ini adalah siswa kelas VIII E dengan
jumlah siswa 38 orang yang terdiri
dari 16 siswa laki-laki dan 22 siswa
perempuan. Pelaksanaan dilakukan
pada semester ganjil tahun ajaran
$2016 / 2017$.

Instrumen yang digunakan untuk memberi perlakuan dalam penelitian ini adalah: (1) lembar observasi aktivitas belajar siswa; (2) lembar observasi guru tentang kegiatan guru dalam pembelajaran; (3) tes tertulis ( tes siklus 1 dan siklus 2).

Teknik pengumpul data yang digunakan peneliti dalam penelitian ini adalah pengamatan langsung yang dilakukan oleh observer dengan menggunakan lembar observasi aktivitas guru dan lembar observasi aktivitas siswa dan teknik tes hasil belajar. Teknik analisa data yang digunakan dalam penelitian ini adalah data yang diperoleh pada kegiatan observasi dari setiap siklus, dianalisis secara deskriptif dengan menggunakan teknik persentase untuk melihat kecenderungan yang terjadi dalam proses pembelajaran kooperatif tipe STAD.

Indikator kinerja ini berfungsi untuk mengukur keberhasilan siswa pada proses pelaksanaan pembelajaran dengan menggunakan model pembelajaran kooperatif tipe STAD. Penelitian ini berhasil apabila minimal $75 \%$ dari jumlah siswa dalam satu kelas dapat mencapai Kriteria Ketuntasan Minimal (KKM) yaitu 74.

\section{HASIL DAN PEMBAHASAN}

Data yang diperoleh selama kegiatan pembelajaran berlangsung terkumpul pada lembar observasi kegiatan pembelajaran yang dilakukan guru, diketahui tingkat keberhasilan yang dicapai baik pada siklus 1 maupun siklus 2. Berikut disajikan hasil analisis yang diperoleh dari lembar observasi kegiatan pembelajaran yang dilakukan guru.

Tabel 4. Analisis kegiatan pembelajaran yang dilakukan guru

\begin{tabular}{|c|c|c|c|}
\hline \multirow[b]{2}{*}{ Deskripsi } & \multicolumn{2}{|c|}{ Siklus 1} & Siklus 2 \\
\hline & $\begin{array}{c}\text { Pertemuan } \\
1 \\
\end{array}$ & $\begin{array}{c}\text { Pertemuan } \\
1 \\
\end{array}$ & $\begin{array}{c}\text { Pertemuan } \\
2 \\
\end{array}$ \\
\hline Terlaksana $(\%)$ & $81,82 \%$ & $90,91 \%$ & $100 \%$ \\
\hline Tidak terlaksana (\%) & $18.18 \%$ & $9,09 \%$ & - \\
\hline \begin{tabular}{l}
\multicolumn{1}{c}{ Dari } \\
pelaksanaan \\
pembelajaran yang dilak \\
pada siklus 1 sudah \\
pertemuan 2, namun \\
kekurangan-kekurangan \\
diperbaiki yaitu pada
\end{tabular} & $\begin{array}{l}\text { diketahui, } \\
\text { kegiatan } \\
\text { cukan guru } \\
\text { baik, yaitu } \\
\text { masih ada } \\
\text { yang perlu } \\
\text { kegiatan }\end{array}$ & \multicolumn{2}{|c|}{$\begin{array}{l}\text { mengarahkan siswa dalam membuat } \\
\text { kesimpulan dan memberikan } \\
\text { penghargaan kepada siswa. Belum } \\
\text { tercapainya hasil yang memuaskan } \\
\text { disebabkan guru tidak melaksanakan } \\
\text { pembelajaran sesuai dengan alokasi } \\
\text { waktu yang ditentukan. Waktu lebih }\end{array}$} \\
\hline
\end{tabular}


banyak digunakan pada kegiatan mengamati objek dan siswa baru beradaptasi dengan model pembelajaran yang disampaikan guru. Sedangkan pada silkus 2 baik dari pertemuan 1 dan pertemuan 2 guru sudah melaksanakan semua tahapan sesuai dengan langkah-langkah pembelajaran pada model kooperatif tipe STAD.

Dalam model pembelajaran kooperatif tipe STAD peningkatan skor individu menentukan skor kelompok. Skor kelompok dihitung dengan mencatat tiap poin kemajuan setiap tim yang diperoleh dari skor dasar dan skor individu yang sesuai dengan kriteria yang sudah ditetapkan. Setiap siswa mengalami peningkatan skor perkembangan kelompok. Kelompok terbaik pada siklus 1 adalah kelompok tiga dengan jumlah skor perkembangan 90 dengan rata-rata skor kelompok 22,5, tergolong kelompok hebat, sedangkan pada siklus 2 semua kelompok sudah mengalami peningkatan dalam skor individu yang tentunya akan berdampak pada peningkatan skor perkembangan kelompok dengan rata-rata skor kelompok 30, tergolong kelompok super.

Sedangkan untuk hasil analisis yang diperoleh dari hasil tes siswa setelah tindakan siklus 1 dan setelah tindakan siklus 2 ternyata proses pembelajaran dengan model kooperatif tipe STAD dapat meningkatkan hasil belajar siswa.

Tabel 5. Nilai rata-rata siswa

\begin{tabular}{ccccc}
\hline No & Deskripsi & $\begin{array}{c}\text { Jumlah } \\
\text { Siswa }\end{array}$ & $\begin{array}{c}\text { Jumlah } \\
\text { Nilai }\end{array}$ & Nilai Rata-Rata \\
\hline 1 & Siklus 1 & 38 & 2500 & 65,79 \\
\hline 2 & Siklus 2 & 38 & 2988,89 & 78,65 \\
\hline
\end{tabular}

Tabel 5 menunjukkan bahwa nilai rata-rata siswa untuk materi Sistem Persaamaan Linear Dua Variabel mengalami peningkatan sebesar 12,86 yaitu nilai rata-rata dari
65,79 pada siklus 1 menjadi 78,65 pada siklus 2. Peningkatan ketuntasan hasil belajar siswa dapat dilihat pada Tabel 6.

Tabel 6. Hasil belajar siswa setiap siklus

\begin{tabular}{cccccc}
\hline Deskripsi & Jumlah & \multicolumn{4}{c}{ Hasil Belajar } \\
\cline { 3 - 6 } & Siswa & Tuntas & $(\%)$ & $\begin{array}{c}\text { Tidak } \\
\text { Tuntas }\end{array}$ & $(\%)$ \\
\hline Siklus 1 & 38 & 18 & $47,37 \%$ & 20 & $52.63 \%$ \\
\hline Siklus 2 & 38 & 29 & $76,32 \%$ & 9 & $23,68 \%$ \\
\hline
\end{tabular}

Adapun ketuntasan siswa dalam kegiatan tes hasil belajar untuk siklus 1 sebesar $47,37 \%$ sedangkan pada siklus 2 mencapai 76,32\%. Dari tabel diketahui persentase siswa yang tuntas mengalami peningkatan. Peningkatan persentase ketuntasan ini terjadi pada siswa-siswa yang tidak 
tuntas pada siklus 1 namun mencapai ketuntasan di siklus 2, hal ini dipengaruhi oleh beberapa faktor yaitu dalam pelaksanaan pembelajaran yang dilakukan guru sesuai dengan rencana pelaksanaan pembelajaran (RPP) dalam model pembelajaran kooperatif tipe STAD , guru sudah lebih baik dalam membimbing kelompok belajar siswa, siswa-siswa lebih aktif dalam diskusi kelompoknya. Peningkatan ketuntasan hasil belajar siswa kelas VIII E SMP Negeri 21 Pontianak selama dua siklus penelitian tindakan kelas, dapat lebih jelas terlihat pada Gambar 1 .

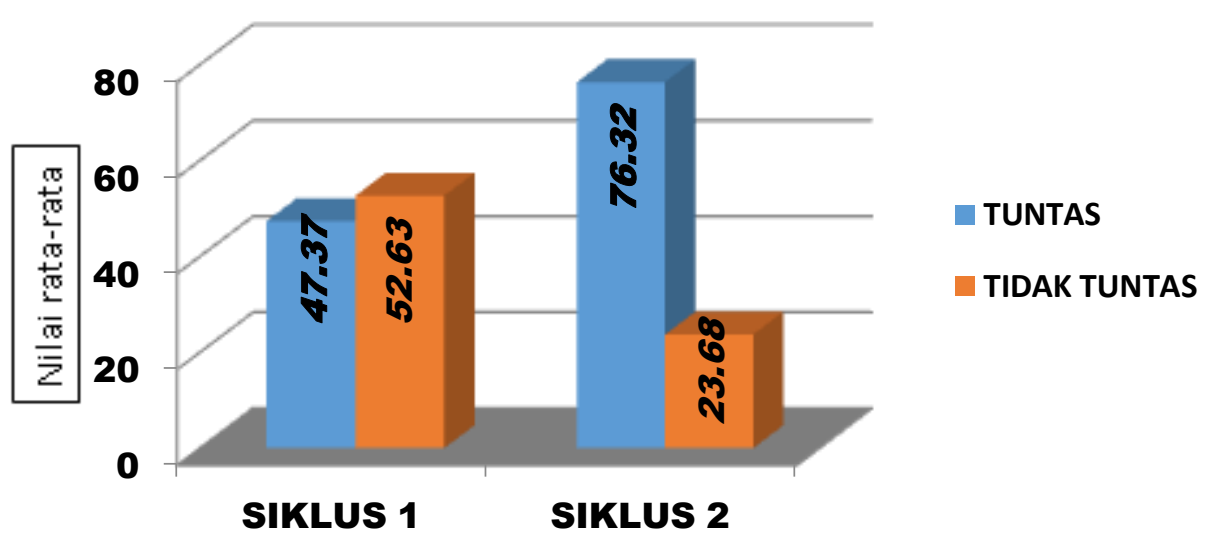

Gambar 1. Persentase hasil belajar siswa setiap siklus

Dari Gambar 1 terlihat terjadi peningkatan hasil belajar siswa yang mencapai KKM 75 sebesar 28,95\%. Secara keseluruhan pada siklus 2 telah terjadi peningkatan hasil belajar siswa dibandingkan dengan siklus 1 . Berdasarkan hasil yang diperoleh dapat dikatakan bahwa penggunaan pembelajaran kooperatif tipe STAD dapat meningkatkan hasil belajar siswa kelas VIII E SMP Negeri 21 Pontianak, menunjukkan bahwa tujuan dari penelitian yang diharapkan sudah tercapai.

Penggunaan model pembelajaran kooperatif tipe STAD dilaksanakan dalam lima tahapan yaitu :

a. Presentasi atau penyajian kelas

Sebelum masuk dalam pembelajaran kelompok, pembelajaran kooperatif tipe STAD diawali dengan penyajian materi yang dilakukan guru secara klasikal dengan menggunakan presentasi verbal atau teks. Penyajian difokuskan pada konsep-konsep materi yang akan dibahas.

b. Kerja kelompok atau tim

Dalam pembelajaran kooperatif tipe STAD siswa dibentuk dalam 9 kelompok. Kelompok yang dibentuk sebaiknya terdiri dari satu siswa kelompok atas, dua siswa kelompok tengah dan satu siswa dari kelompok bawah. Kelompok terdiri dari 4-5 siswa yang mewakili dari seluruh bagian dari kelas baik dalam hal akademik maupun jenis kelamin. Fungsi dibentuknya kelompok adalah untuk saling menyakinkan bahwa setiap anggota kelompok dapat bekerja sama dalam belajar. Masingmasing kelompok diberikan lembar 
diskusi yang berisi beberapa permasalahan mengenai materi yang dibahas untuk dipecahkan secara bersama. Ketika mendiskusikan masalah, kerja pada kelompok yang paling penting adalah memperbaiki setiap kekeliruan apabila teman sesama dalam kelompok membuat kesalahan. Lebih khusus lagi untuk mempersiapkan semua anggota kelompok dalam menghadapi tes individu dan mencetak poin yang tinggi untuk kelompoknya.

\section{c. Tes atau kuis}

Kuis atau tes dilaksanakan setelah presentasi diskusi kelompok oleh masing-masing kelompok selesai. Tes atau kuis bertujuan untuk mengetahui kemampuan siswa setelah mengikuti pembelajaran dengan model pembelajaran kooperatif tipe STAD.

d. Skor kemajuan individu

Dalam model pembelajaran kooperatif tipe STAD peningkatan skor individu menentukan skor kelompok. Skor kelompok dihitung dengan mencatat tiap poin kemajuan setiap tim yang diperoleh dari skor dasar dan skor individu yang sesuai dengan kriteria yang sudah ditetapkan. Setiap siswa mengalami peningkatan skor perkembangan kelompok. Kelompok terbaik pada siklus 1 adalah kelompok tiga dengan jumlah skor perkembangan 90 dengan rata-rata skor kelompok 22,5, tergolong kelompok hebat, sedangkan pada siklus 2 semua kelompok sudah mengalami peningkatan dalam skor individu yang tentunya akan berdampak pada peningkatan skor perkembangan kelompok dengan rata- rata skor kelompok 30, tergolong kelompok super.

e. Penghargaan Kelompok

$$
\text { Penghargaan kelompok }
$$

dilakukan dengan memberikan penghargaan atas usaha yang telah dilakukan kelompok selama belajar. Hal ini dimaksudkan untuk meningkatkan motivasi masingmasing siswa dalam mengikuti pembelajaran. Dalam hal ini kelompok terbaik adalah kelompok dua dengan predikat kelompok super dengan perolehan skor kelompok 100 dan rata-rata kelompok 25 dan dalam pengerjaan lembar kerja siswa adalah kelompok tercepat dengan nilai 100.

\section{SIMPULAN DAN SARAN}

Berdasarkan analisis terhadap data penelitian tindakan kelas, dapat disimpulkan bahwa penggunaan model pembelajaran kooperatif tipe Student Team Achievement Division (STAD) dapat meningkatkan hasil belajar siswa pada materi Sistem Persamaan Linear Dua Variabel di kelas VIII E SMP Negeri 21 Pontianak. Secara khusus, hasil penelitian ini adalah sebagai berikut:

1) Peningkatan hasil belajar terlihat dari hasil tes setiap siklus, dimana pada siklus pertama persentase siswa yang tuntas $47,37 \%$ meningkat sebanyak $28,95 \%$ menjadi $76,32 \%$ pada siklus kedua. Jumlah siswa yang tuntas pada siklus 1 sebanyak 18 orang, terjadi peningkatan pada siklus 2 sebanyak 11 orang sehingga menjadi 29 orang siswa.

2) Aktivitas guru selama proses pembelajaran dengan menggunakan model pembelajaran kooperatif tipe STAD mengalami peningkatan. 
Pada siklus 1 persentase aktivitas guru sebesar $86,37 \%$ meningkat menjadi $100 \%$ pada siklus 2 .

3) Aktivitas siswa dalam diskusi kelompok juga meningkat terlihat dari siswa yang semula kurang aktif pada siklus 1 menjadi lebih aktif pada siklus 2. Siswa-siswa yang pandai mulai bisa berbagi pengetahuannya dengan siswa yang kurang pandai dalam satu kelompok sehingga siswa bersama-sama mencapai ketuntasan dalam belajar. Hal ini terlihat dari perkembangan skor kelompok. Antusias siswa dalam pembelajaran lebih baik dari pembelajaran yang dilakukan guru sebelumnya.

Berdasarkan uraian mengenai penelitian tindakan kelas yang telah dilaksanakan, maka peneliti memberikan saran-saran kepada peneliti selanjutnya, guru dan sekolah sebagai berikut :

1. Dalam pembelajaran matematika hendaknya bervariasi dan tidak monoton sehingga hasil pembelajaran dapat lebih maksimal.

2. Agar pembelajaran dapat berhasil dengan baik maka seorang guru hendaknya selalu aktif dalam melibatkan siswa selama pembelajaran berlangsung, menarik serta konstuktif agar kegiatan dalam proses belajar mengajar menjadi lebih baik dan menyenangkan bagi siswa.
3. Guru hendaknya benar-benar menguasai pengelolaan kelas, memberikan kesempatan kepada siswa untuk bertanya, menyampaikan pendapat dan mengembangkan pengetahuan yang seluas-luasnya.

\section{DAFTAR PUSTAKA}

Dimyati \& Mujiono. (2006). Belajar Dan Pembelajaran. Jakarta: Rineka Cipta.

Idayani, S. (2010). Meningkatkan hasil belajar Matematika Melalui Model Pembelajaran Kooperatif Tipe Student Team Achievement Division (STAD) pada Siswa Kelas VIII D SMP $N 21$ Pontianak. Pontianak: FKIP PONTIANAK (tidak dipublikasikan).

Rochmatin \& Gunansyah, G. (2014). Penerapan Model Pembelajaran Kooperatif Tipe STAD Meningkatkan Hasil Belajar Siswa Dalam Pembelajaran IPS kelas IV. Jurnal PGSD, Vol. 2, No. 3, 18 .

Trianto. (2010). Mendesain Model Pembelajaran InovatifProgresif, Konsep, Landasan Dan Implementasinya Pada Kurikulum Tingkat Satuan Pendidikan (KTSP). Jakarta: Kencana. 